\title{
Pengaruh two stay three stray terhadap kecerdasan linguistik siswa Sekolah Dasar
}

\author{
Arief Rahman Hakim, Andika Gutama \\ Universitas Kanjuruhan Malang \\ ariefrahmanhakim@unikama.ac.id, andika@unikama.ac.id
}

\begin{abstract}
Abstrack
A good learning process must be able to make students become excited and play an active role. The purpose of this study was to determine the effect of the Two Stay Three Stray learning model on students' linguistic intelligence. This research is a quasy experimental study with a sample of 50 fourth grade students of SDN Lumbang II, Lumbang District, Probolinggo Regency. The instruments used were observation and questionnaire. The data analysis technique used independent sample t-test. Hypothesis test results obtained significance value of 0.044 and Ha accepted. Based on the results of the study note that there is a significant influence between the Two Stay Three Stray Stray learning model on students' linguistic intelligence.
\end{abstract}

Keywords : Learning Model, Cooperative, Two Stay Three Stray, Multiple Intelligence, Linguitic Intelligence

Abstrak

Proses pembelajaran yang baik harus mampu membuat siswa menjadi bersemangat dan berperan aktif. Tujuan dari penelitian ini adalah untuk mengetahui pengaruh model pembelajaran Two Stay Three Stray terhadap kecerdasan linguistik siswa. Penelitian ini merupakan penelitian kuantitatif quasy eksperimen dengan sampel 50 siswa kelas IV SDN Lumbang II Kecamatan Lumbang Kabupaten Probolinggo. Instrumen yang digunakan adalah observasi dan angket. Teknik analisis data menggunakan independent Sample t-test. Hasil uji hipotesis diperoleh nilai signifikasi sebesar 0,044 dan Ha diterima. Berdasarkan hasil penelitian diketahui bahwa ada pengaruh signifikan antara model pembelajaran Two Stay Three Stray Stray terhadap kecerdasan linguistik siswa.

Kata Kunci : Model Pembelajaran, Kooperatif, Two Stay Three Stray, Multiple Intelligence, Kecerdasan Linguistik

\section{Pendahuluan}

Belajar merupakan proses perubahan perilaku baik kognitif, afektif maupun psikomotor. Sehingga belajar hanya dialami oleh pribadi siswa itu sendiri, artinya siswa merupakan penentu terjadi atau tidaknya proses belajar. Pembelajaran yang menarik harus dikemas sedemikian rupa agar membuat siswa menjadi bersemangat dan berperan aktif dalam proses tersebut. Siswa yang bersemangat membuat jalannya pembelajaran menjadi lebih hidup dan memiliki arti bahwa pembelajaran yang dilakukan pada hari itu tergolong pembelajaran yang sukses.

Menurut (Jasmine, 2007) Multiple Intellegences adalah validasi penting seorang individu atas perbedaannya terhadap individu lain. Dalam dunia pendidikan teori ini sangat bergantung pada pengakuan, pengenalan, dan 
penghargaan terhadap cara siswa belajar, disamping minat dan bakat masing masing siswa.

Hasil observasi yang dilakukan pada siswa kelas IV SDN Lumbang II menunjukkan bahwa siswa cenderung pasif dalam berbicara maupun bertindak. Hanya diam mendengarkan ketika guru menjelaskan tanpa ada interaksi langsung antara guru dan siswa, beberapa siswa terlihat mengantuk mendengarkan ceramah dari guru, siswa kurang konsentrasi dan tidak bersemangat mengikuti jalannya kegiatan pembelajaran. Prilaku siswa dalam proses pembelajaran ini menimbulkan pembelajaran di kelas menjadi pasif dan cenderung membosankan sehingga siswa kurang mendapat kesempatan dalam mengembangkan kecerdasan lingustiknya.

Menurut (Armstrong, 2017) menyatakan bahwa "kecerdasan linguistik mencakup kemampuan untuk menggunakan kata secara efektif baik secara lisan maupun tertulis". Kecerdasan bahasa seorang anak ditunjukkan dalam kemampuanya dia dalam bercerita, kamampuan menulis, dan perkembangan memorinya yang berbeda dengan anak-anak usianya. Dalam hal lain, seorang anak yang memiliki kecerdasan bahsa yang baik terlihat dari kegemaranya dalam membaca buku. Disamping itu suka mendengar cerita yang disampaikan orang lain.

(Hakim, 2017) berpendapat "pembelajaran kooperatif merupakan suatu pembelajaran yang mampu melibatkan keaktifan seluruh siswa dalam proses pembelajaran". Melalui pembelajaran tersebut siswa diarahkan untuk belajar bersama-sama, saling menyumbangkan pikiran dan bertanggung jawab terhadap pencapaian hasil belajar baik secara individu maupun kelompok. Salah satu model pembelajaran kooperatif adalah Two Stay Two Stray. Menurut (Suprijono, 2009) model pembelajaran kooperatif ini selain dapat meningkatkan hasil belajar siswa juga mampu mengembangkan rasa toleransi dan mampu menerima keragaman, serta dapat mengembangkan keterampilan social yang lain. Hal ini dikarenakan bahwa model ini menuntut siswa untuk saling bekerjasama.

\section{Metode}

Peneliti menggunakan penelitian eksperimen semu dengan pendekatan kuantitatif. Desain yang digunakan adalah nonequivalent control group design. Penelitian ini dilaksanakan pada bulan Juli 2018 di SDN Lumbang II Kecamatan Lumbang Kabupaten Probolinggo Tahun Ajaran 2017/2018. 
Alat pengumpulan data yang digunakan adalah angket kecerdasan linguistic, yang disertai lembar observasi, wawancara dan studi dokumentasi untuk mempertegas hasil perhitungan angket tersebut. Sampel penelitian berjumlah 50 siswa yaitu 25 siswa kelas IV-A sebagai kelas kontrol dan 25 siswa kelas IV-B sebagai kelas eksperimen.

Penelitian ini mempunyai dua variabel yaitu satu variabel bebas dan satu variabel terikat. Variabel bebas adalah perlakuan dalam pembelajaran yaitu model pembelajaran Two Stay Three Stray (X). Sedangkan variabel terikatnya adalah Kecerdasan Linguistik (Y).

\section{Hasil dan Pembahasan}

Uji prasyarat yang digunakan meliputi uji normalitas Kolmogorov Smirnov dan uji homogenitas Test of Homogeneity of Variance dengan bantuan program SPSS 22.0 for windows dengan hasil analisis sebagai berikut:

Tabel 1 Hasil Uji Normalitas

\begin{tabular}{|c|c|c|c|}
\hline & & EKSPERIMEN & KONTROL \\
\hline $\mathbf{N}$ & & 25 & 25 \\
\hline \multirow{2}{*}{ Normal Parameters ${ }^{\mathbf{a}, \mathbf{b}}$} & Mean & 76,83 & 57,53 \\
\hline & Std. Deviation & 2,244 & 2,493 \\
\hline Kolmogorov-Smirnov Z & & ,479 & ,667 \\
\hline Asymp. Sig. (2-tailed) & & ,997 &, 765 \\
\hline
\end{tabular}

Berdasarkan Tabel 1 tentang hasil pada uji normalitas skor angket kecerdasan linguitik dengan taraf signifikan lebih dari 0,05, sehingga dapat disimpulkan bahwa data skor angket kecerdasan linguistik pada kelas eksperimen dan kelas kontrol terdistribusi normal.

Tabel 2 Hasil Uji Homogenitas

\begin{tabular}{rlrrr}
\hline $\begin{array}{c}\text { Levene } \\
\text { Statistic }\end{array}$ & df1 & df2 & Sig. \\
\hline, 131 & 1 & 48 &, 719 \\
\hline
\end{tabular}

Berdasarkan Tabel 4.13 dapat diketahui bahwa nilai signifikan sebesar 0,719. Nilai signifikansi $0,719>0,05$, maka dapat disimpulkan data angket kecerdasan linguistik kelas eksperimen dan kelas kontrol homogen. 
Tabel 3 Uji Hipotesis Penelitian

\begin{tabular}{|c|c|c|c|c|c|c|}
\hline Kelompok & Pengukuran & $\mathbf{t}$ & df & MD & Sig. & $\begin{array}{c}\text { Std. } \\
\text { Error }\end{array}$ \\
\hline Eksperiment-Kontrol & $\mathrm{T} 1-\mathrm{T} 2$ & 1,938 & 48 & 1,360 & 0,44 & 0,702 \\
\hline
\end{tabular}

Hasil hipotesis kecerdasan linguistik dari tabel 3 diperoleh nilai signifikan 0,044 Karena nilai signifikan $(0,044<0,05)$. Maka, Ho ditolak dan Ha diterima. sehingga dapat disimpulkan bahwa ada pengaruh yang signifikan antara model pembelajaran Two Stay Three Stray terhadap kecerdasan linguistik siswa kelas IV di SDN Lumbang II Kecamatan Lumbang Kabupaten Probolinggo.

Kecerdasan Linguistik siswa dapat diketahui berdasarkan data yang diolah peneliti, berdasarkan data tersebut kita dapat ambil kesimpulan bahwa ada pengaruh yang baik dari kecerdasan linguistik. Hal ini dibuktikan ketika proses pembelajaran berlangsung, siswa pada kelas eksperimen pada prosesnya siswa aktif berbicara dan berkomunikasi pada kegiatan kegiatan yang ada pada model pembelajaran yakni diskusi, tanya jawab dan presentasi.

Keaktifan berbicara dan keberanian siswa dalam berbicara tersebut sejalan dengan penelitian (Hamiddin, 2012) yang menyatakan bahwa model pembelajaran Two Stay Three Stray dapat meningkatkan keberanian dan keaktifan siswa dalam membaca puisi di depan kelas. Penelitian lain (Annas, 2018) menunjukkan bahwa motivasi kemampuan berbicara siswa dalam matapelajaran Bahasa Inggris juga meningkat melalui penggunaan model Two Stay Three Stray.

Pada proses diskusi, sebagian besar siswa melakukannya dengan serius dan benar benar semangat, dan proses diskusi menurut peneliti berlangsung dengan baik dan membuahkan hasil yang memuaskan, hal ini ditunujkkan dengan kekompakan mereka dalam bertukar pendapat serta mendengarkan pendapat siswa yang lain. Pada proses kegiatan tanya jawab, sebagian besar siswa melakukannya dengan antusias yang tinggi, ini terbukti dengan banyaknya atensi yang dilakukan siswa ketika peneliti memberikan umpan balik ataupun siswa lain membacakan hasil diskusi kelompoknya.

Sejalan dengan pendapat tersebut menurut (Pangaribuan, 2013) "penerapan pembelajaran kooperatif tipe two stay two stray dapat meningkatkan aktivitas belajar". Penggunaan model pembelajaran kooperatif ini menutut siswa untuk 
membagikan hasil dan informasi hasil diskusi kepada kelompok lain. Dengan demikian proses pembelajaran berlangsung dapat memberikan variasi metode seperti diskusi, dan tanya jawab sehingga menuntut siwa untuk berpartisipasi secara aktif dalam pembelajaran. Hal ini dilakukan karena banyak kegitan belajar mengajar yang yang diwarnai dengan kegiatan-kegiatan individu.

Atensi siswa ditunjukkan dengan banyaknya siswa yang mengacungkan tangan ketika ada suatu pertanyaan atau umpan balik yang guru berikan. Pada kegiatan presentasi, sebagian besar siswa menunjukkan apresiasi mereka terhadap siswa lain berupa perhatian serta tanggapan maupun sanggahan yang diberikan kepada siswa lain.

Sikap positif yang mereka tunjukkan dengan cara saling berebutnya kelompok mereka untuk maju dan membacakan hasil diskusi mereka. Ini berarti mereka telah memiliki kemampuan berbicara yang mumpuni serta memiliki rasa percaya diri yang tinggi dan itu merupakan suatu sikap yang baik dan positif bagi siswa sendiri untuk bekal mereka selanjutnya.

Sejalan dengan pendapat dari penelitian yang lain, yang dilakukan oleh (Rahayu, 2013) di SDN Salakan Lor, Kabupaten Sleman menunjukkan bahwa penggunaan pembelajaran Multiple Intelligences dapat meningkatkan hasil belajar IPS pada ranah kognitif, Afektif dan ranah psikomotor. Dengan demikian dapat kita tarik kesimpulan bahwa Kecerdasan Linguistik dapat meningkat dengan menggunakan model pembelajaran Two Stay Three Stray.

\section{Simpulan}

Berdasarkan analisis data yang dilakukan peneliti dapat ditarik kesimpulan bahwa adanya pengaruh kecerdasan linguistik kepada siswa kelas IV SDN Lumbang II Kabupaten Probolinggo sebesar 0,008 dan angka ini menunjukkan bahwa ada pengaruh yang signifikan antara model pembelajaran Two Stay Three Stray terhadap kecerdasan linguistik siswa.

\section{References}

Annas. (2018). Technique to develop young learners' speaking. English education journal, 9(3), 422-442. 
Armstrong, t. (2017). Multiple intelligences in the classroom, 4th edition. Ascd.

Hakim, a. R. (2017). Kolaborasi model fun-n-pick dan team game tournament dalam meningkatkan self esteem. Pedagogia: jurnal pendidikan, 6(1), 14-25.

Hamiddin. (2012). Improving students ' comprehension of poems using two staytwo stray strategy hamiddin. Vidya karya, 27(1), 1-8.

Jasmine, j. (2007). Panduan praktis mengajar berbasis multiple intelegences. Bandung: nuansa.

Pangaribuan, r. (2013). Model kooperatif tipe two stay two stray meningkatkan aktivitas belajar model kooperatif tipe two stay two stray meningkatkan aktivitas belajar. Jurnal pendidikan dan pembelajaran khatulistiwa, 2(3).

Rahayu, p. (2013). Upaya meningkatkan hasil belajar ips melalui strategi multiple intelligences pada siswa kelas vi sd n salakan lor. Ejournal mahasiswa universitas negeri yogyakarta, 2(2).

Suprijono, a. (2009). Cooperative learning teori dan aplikasi paikem. Yogyakarta: pustaka pelajar. 